DOI: $10.22559 /$ folklor.1081

folklor/edebiyat, cilt: 25 , sayl: 100, 2019/4

\title{
Taita Imbabura: Reverence and Mirth in Mountain Worship
}

\section{John McDowell}

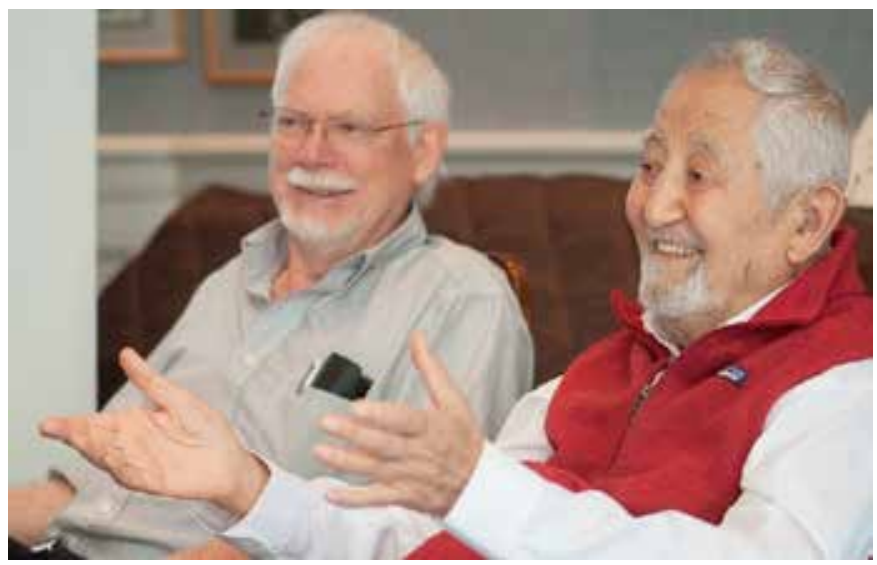

John McDowell, with Professor Basgoz, at a discussion of his work at Indiana University

\section{$\underline{\text { Dedication }}$}

I dedicate this essay to my good friend and longtime colleague at Indiana University, Ilhan Basgoz. I have learned much from Ilhan, an astute student of culture, in particular, of narratives and the ways they shape people's understandings of the world. I believe that the theme I develop in this essay, having to do with stories and systems of belief in an Andean society where I had the privilege to do ethnographic research, owes much to Ilhan's influence on my thinking and scholarship.

\footnotetext{
* Prof.Dr., Indiana University, mcdowell@indiana.edu
} 


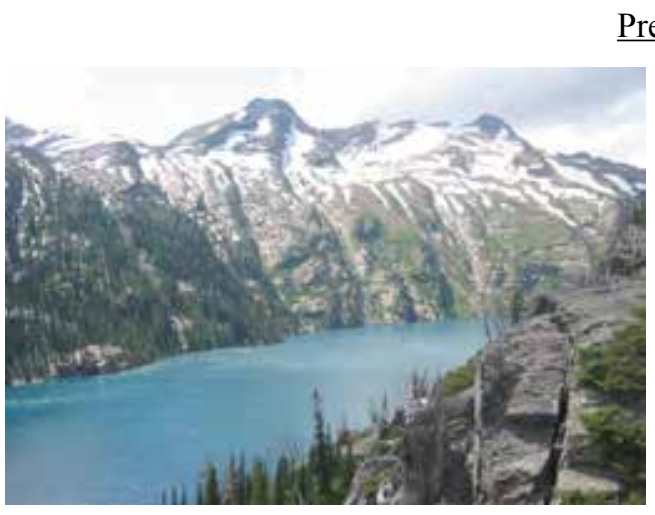

Turquoise Lake, in the Mission Mountains of Montana, one of my favorite hiking destinations

With family roots in the Rocky Mountains of Montana, I have always sought the fresh air and vistas of the high places, and this quest led me, eventually, to the high Andes Mountains on the South American continent. In the Andes region of South America, for many a century people have followed the rivers to their highland sources and walked to the edge of the glaciers, to carry out rituals connecting themselves and their communities to the sources of spiritual power. Tied to these beliefs and practices is a rich Andean mythology of mountain spirits. In this paper, I venture into the Andean highlands to explore mythic narratives tied to beliefs and practices associated with Volcán Imbabura, an imposing volcano of northern Ecuador rising to an elevation of 4,630 meters above sea level and towering over the populated corridor running from Ibarra at the north to Otavalo at the south. The purpose of this venture is to explore apparently contradictory tendencies in mountain worship, and by extension, to further complicate facile notions of spiritual or religious experience.

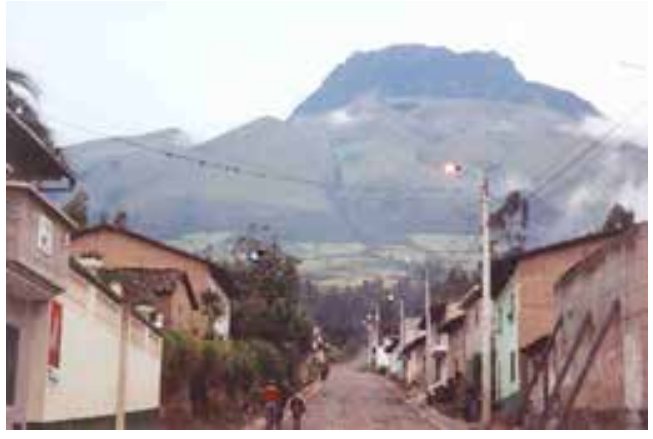

Taita Imbabura, the volcano, arises above the town of Ilumán, near Otavalo Ecuador

\section{Taita Imbabura}

I address here a curious juxtaposition of mirth and reverence in beliefs and practices associated with Taita Imbabura, Father or Lord Imbabura, a mountain deity of consequence for the Otavalo Runa of northern Ecuador. The Otavalo Runa are a collectivity of Quichua-speaking communities residing in the city of Otavalo and in the many indigenous towns and villages on its perimeter, numbering some 70,000 people in all, though many of these are scattered about in an Otavalan Runa diaspora that includes South Korea, a number of countries in Europe, the United States, Canada, Brazil, and Mexico, among other sites, In Turkey - I encountered a troop of Otavalo musicians when I was in Istanbul in 2012. Most Otavalo Runa settlements - towns, villages, and a few small cities such as Peguche and Ilumán - lie on the flank of Volcán Imbabura, a massive volcanic peak towering over Otavalo - these people have their homes on the mountain, plant their crops on its shoulders, and conceive of the mountain's spirit as a living influence in their daily lives. 


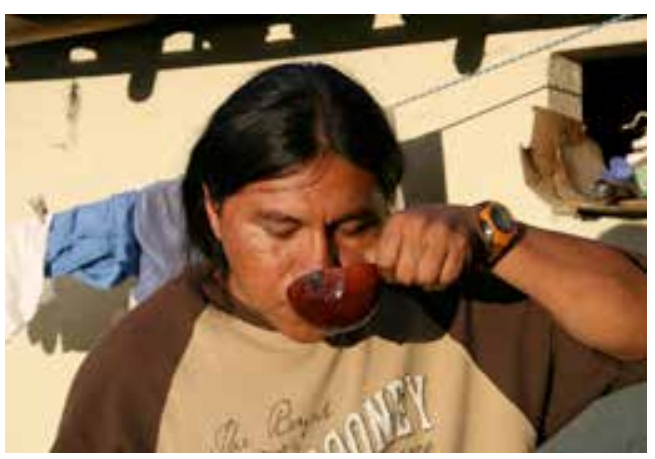

Alonso enjoys a sip of maize beer

I first became aware of the routine presence of Taita Imbabura in Otavalo Runa thought when my friend and companion Alonso Diáz Pichamba blamed a spate of bad weather on the intrusion of new farming higher up the slopes of the mountain. "No le gusta, el Taita," he told me; "he doesn't like it, the Lord."

Alonso chimed in that the taita doesn't like it when lots of people go up him, and he will send down rain or snow and force them to turn back. Also, when people go to the upper slopes and start burning to open fields, taita gets angry and sends storms down on them. Further evidence of a tendency to personalize the mountains. (From my field notes)

It was striking to me, not only that Alonso held an active belief in the existence of this mountain spirit, but also, that he felt a certain personal intimacy with this spirit, such that he could profess knowledge of its sentiments. As my acquaintance with the region deepened, I found that Alonso's attitude was typical and that people living in the shadow of the volcano routinely intuited the feelings of the mountain spirit and projected features of their own experiences onto it. Taita Imbabura, it seemed, was a constant companion, a familiar presence, almost a confidant, of the indigenous people residing in its vicinity.

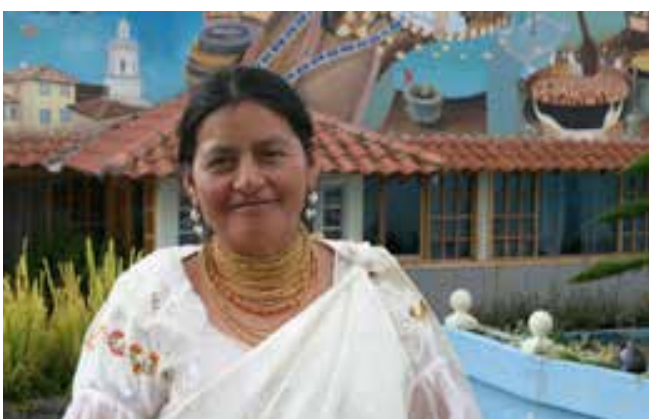

Maruja, a wise woman of the Andes

In this vein, Maruja, the senior woman in my extended family in Ilumán, one of the Runa communities on the slope of Taita Imbabura, felt inspired and protected by her personal relationship with the Taita:

When walking about or crossing lonely spaces, she prays to Diosito and calls on the aid of urqu taita, Imbabura mountain father. And she has been fortunate in this way, rarely falling under the influence of evil spirits. She even offers herselfas a curerfor Michael, should he need another cleansing, as she is strong enough that the evil will not lodge in her. (From my field notes; "a curer for Michael" refers to the evening she performed a curing ceremony on my son, who had been affected by the spirit of the mountain.) 


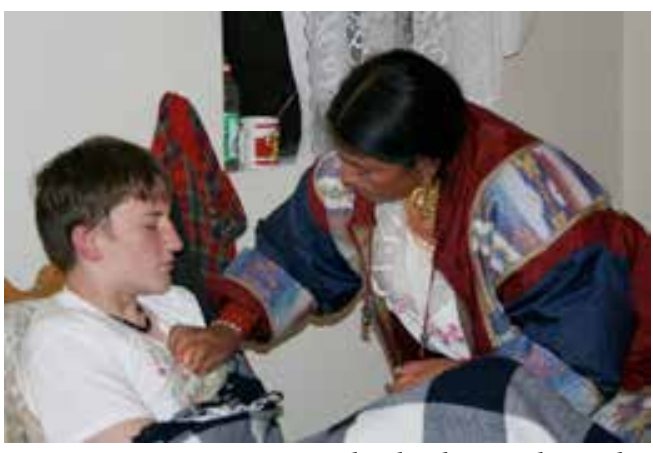

Maruja cures our son Michael, who was hit with spirit sickness on the mountain
But this personal connection, I soon learned, was part of a larger system of religious belief and practice that infuses the curing ceremonies and other rituals vital to the Otavalo Runa. These range from the most public of events, for example, the annual purification of the community at the pukyu San Juan, to informal curing sessions in private homes. The gathering of yachaks, native healers, at the San Juan pukyu - pukyus are sites of spiritual activity, usually associated with water - is an important assembly of the communities:

The water that emerges at Pukyu San Juan is pure and Maruja's grandparents taught her that it comes from deep within Taita Imbabura. The yachaks go there at the start of the corn harvest to initiate a year's round of sacred activities. They carry the corn stalk into the water to thank the gods for this years' crop. They bring a pot with burning coal, fragrant wood, and fragrant plants, as "una adoración al sol, al viento, al la temporada de la cosecha" ("to revere the sun, the wind, at the season of the harvest"). (From my field notes)

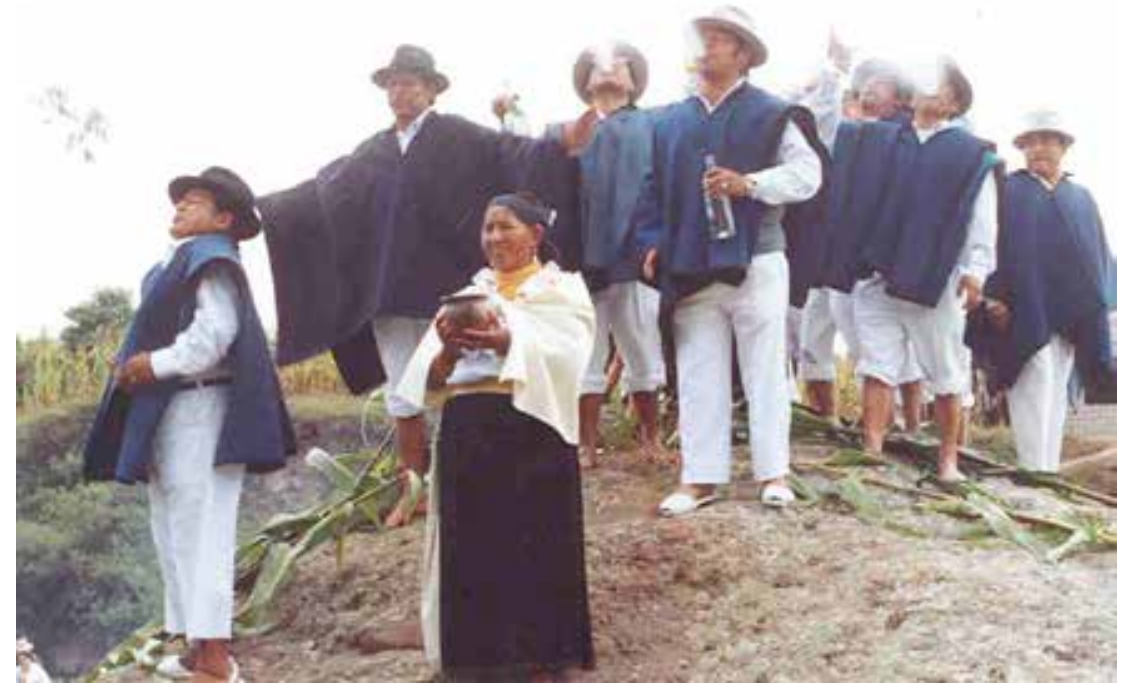

The yachaks conduct a ritual cleansing at pukyu San Juan

These and other public ceremonies include prayers that are released to the mountain deity during the annual carnival season and at other key ritualized moments in the Otavalo Runa cosmology. Michelle Wibbelsman (2005: 178) argues that these events have gained a new significance with the movement of the people away from home in search of economic activity: 
"As Otavaleños travel outwardly, the geographical, technological, and social dislocations they experience seem to produce a new awareness of their cultural and mythical heritage, leading them back through ritual and memory to an understanding of centralizing concepts that define their sense of commonality."

In all of these settings, from the most private to the most public, speakers invoke the presence and the power of Taita Imbabura to overcome the evil influences that can invade the person or the body politic. In these prayers and ritual speeches, Taita Imbabura appears as a primary figure, in many cases, the primary figure, in a broader constellation of powers that features both Christian and indigenous elements. The strong Catholic faith that predominates in these communities provides Jesus Christ, the Virgin Mary, and a collection of saints, some of them folk saints, as powers whose beneficence can be solicited. Taita Imbabura is primary among another set of powers - deities, forces, and spirits associated with the natural landscape.

\section{Reverence}

Before turning to the mythology tied to Taita Imbabura, we will do well to visit a typical curing ceremony in order to inspect the most typical context in which Taita Imbabura is invoked. When a child has a persisting cough, when a friend or neighbor has come down with a fever, when a person has suffered an accident or had their property stolen or damaged - these are occasions that merit a curing ceremony. If the matter is serious, a ritual specialist will be brought into the home, or visited; if it is a lesser matter, a ranking adult in the immediate or extended family will draw upon widely shared medicinal practices to perform the cure.

The cure begins with an invocation of Taita Imbabura; I was told by my Otavalo Runa compadre, Luis Alberto Yamberla, that "before starting the cure, one must solicit the help of the mountain, because the power comes from there." Luis Alberto continues: "For the indigenous person, Lord Imbabura is truly powerful: in these curing ceremonies, he provides the power, the energy."

Here are the words spoken, or intoned, in Quichua, to invoke el taita, along with the other spiritual helpers:

Imbabura taitico urcu mamita, yacu mamita yanapawangui rosas pukyu kindi pukyu sanjuan pukyu yanapawangui

Dear Lord Imbabura, Mother Mountain, Mother Water, please help me. Rosas spirit, Hummingbird spirit, San Juan spirit, please help me.

Kinchi mamita, baños mamita, lajas mamita Señor de las angustias taitico, de buena esperanza taitico Carmen mamitagu mundu taitico ayudawangui

Virgin of Kinchi, Virgin of Baños, Virgin of Las Lajas, Our Lord of the Anguish, Dear Father, of Good Hope, Dear Father, Dear Sweet Virgin Carmen, Dear Lord of the World, come to my help.

The first set of references here is to the nature spirits found in the most important pukyus in the region; the second set invokes apparitions of the Virgin Mary and prominent Catholic shrines in the region.

Then the curing begins, and these words are spoken, chanted, and sung:

Anchuri

Llugshi mapa
Go away!

Get out, filth 
Kai wawata waglichikungui

Llugshi carajo

Alichingapa kaipi irquita
You are harming my child

Get out, dammit!

Cure him of this sickness.

This verbal component is part of a larger web of activities going into the curing process, including, prominently, these elements:

1. The candle: Candles play an important role in diagnosing the person who is sick; by concentrating and meditating, the doctor can find images in the flame that will offer clues about the illness. For example, Luis Alberto explained: "In the candle, with clarity, a foot appears, my foot, they have done a little harm to me, they have grabbed my footprints, they get them, they throw in salt, needles, and one gets sick; 'there it is, look,' and I saw it."

2. Alcohol and tobacco. These are used as cleansers, taking away the bad spirits that can afflict and actually inhabit the person. Luis Alberto explains that they "take away the filth, of the bad spirits; the evil hour, in the creek-beds; if that gets to you, for certain you arrive home without energy, because the bad wind hit you." Luis Alberto uses the Quichua term wayrashka, which is built on the noun, "waira," meaning "wind" or "spirit," with the past participle, -shka, tacked on, to signify "cursed" or "bewitched." I like to translate this key term as "struck by spirit sickness."

3. A rubbing with egg, or with a small coin. Luis Alberto says: "For this process, it is not necessary to be a native doctor, all the indigenous people have this, it's part of our culture, the indigenous medicine."

4. Blowing with spittle, known as fukui in Quichua. Luis Alberto describes this as follows: "The patient with arms extended, blowing from the feet to the head, and from behind, the same thing; once you do the blowing, you quickly have to rub the patient."

5. Fragrance. The antidote for salt is cinnamon, and sweet-smelling items are used to counteract the harsh effects of salt.

6. Spirit stones of the volcano, known as urcu rumi in Quichua. These are stones found on the slopes of Taita Imbabura; according to Luis Alberto, this is what gives them their power. He says: "they are very smooth and black, just black; they don't appear to just anybody, to anyone's eyes; only to those who have connections to the native doctors." Luis Alberto continues: "Blowing on them, if they sweat like with a color, yes, it is a mountain stone."

7. The nettle (a plant that stings). Luis Alberto calls this wagratsini or llamastini (based on the words for "cow" and "llama," respectively) and he notes: "with this you cleanse them; rubbing with both hands, and singing a song from the ancestors."

8. Flowers such as the rose and the carnation. He tells me: "you chew up the carnation, and you have to give it a blowing over the body").

Luis Alberto concluded my lesson on Otavalo Runa curing methods with these words: "The person must not bathe for three days, nor should they shake hands with anyone; and they cannot eat grease - the flesh of the pig is prohibited. And after three days, you bathe yourself in medicinal water containing plants from our own community."

We see from this account of the curing techniques used by specialists, and also, to 
some extent by all competent Otavalo Runa adults, that Taita Imbabura is an object of deep reverence, the primary source of spiritual power that is used to turn away spiritual sickness. His name and presence are invoked at the outset of curing ceremonies, his slopes are the source of the powerful urcu rumi, spirit stones of the volcano, and the waters of the pukyus, sacred mountain shrines, emerge from his body. Taita Imbabura is first among equals in a set of spiritual agents that includes both Catholic figures and natural forces and figures populating the Ecuadorian landscape.

Reverence is established; what about mirth?

\section{$\underline{\text { Mirth }}$}

To get at the mirth factor, we will delve into mythology of the Otavalo Runa. This mythology features tales of nature deities, principally mountains and lakes, in a region of spectacular natural beauty. There are many mythic narratives with reverential qualities, but the stories with Taita Imbabura as protagonist tend toward the comical, often with the Taita as the butt of the joke. These are stories that are widely known and relished when people sit together and share the wisdom of their ancestors.

My Otavalo Runa friends, Luis Alberto and Maruja, stressed to me in conversation the importance they attach to this oral tradition. Maruja, in these words she shared with me, emphasizes the importance of carrying the mythic narratives forward through the generations, as these stories, in her sight, are precious resources for thinking about who we are:

Like this, spoken in this way, so that everyone, all of us would know it, some of our grandparents would speak in this way, they would speak like this and we are also speaking in this way. I have spoken like this and I speak like this, because it is useless to make things up, like this everyone comes to tell these stories, they are coming to an understanding.

Perhaps some families have been careless, and they don't know this history, you know? But people who are responsible to their children, one day they grow up, they get married, and they tell their children about what happened in the past. These things come from the ancient times, from old times into the present.

For me, they talked like this, and I would listen. My dear grandmother would say to me: "My child, and all of you, pay attention, all of you, be careful, you will see, one day, you will not be little any more, you will grow, you will get married, and you will tell these stories to your little ones," that's how she would advise us.

So I have these stories that they told me. And these are for us to reflect on, to gain understanding.

With this framing of the genre's important functions, it will come as a surprise that the best-known stories about Taita Imbabura are playful in tone, or even slightly demeaning. Let's inspect three examples.

\section{Story1: "Taita Imbabura"}

First, I offer the text of a story, as documented in Quichua by anthropologist Ruth Moya, and accompanied by my English translation, of Taita Imbabura as a young man entering into a relationship with a woman mountain, Cotacachi, across the valley: ${ }^{1}$ 


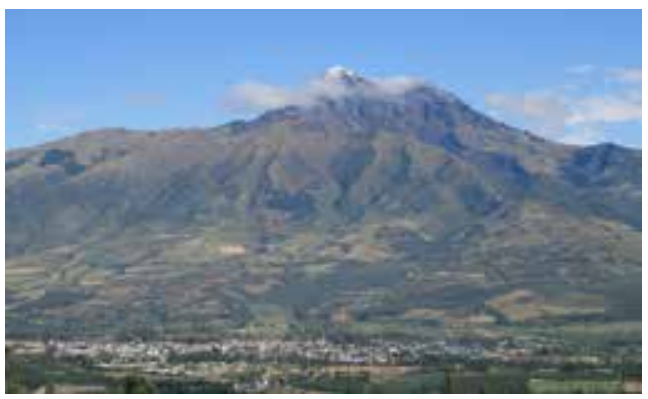

Mama Cotacachi, seen from slopes of Taita

\section{Imbabura}

This mountain still being a child, he lived, they say, getting along well with the other mountains.

Playing with them, he walked all over, living happily in that way.

One day he began to get acquainted with a woman mountain, and that mountain is called Cotacachi.

Getting acquainted like that, the two of them walked all over, they say.

Just walking about like that, one day

Imbabura mountain said to that mountain:

"I say I want you to become my wife."

And again the woman mountain just the same:

"I want you to become my husband," she said.

Then like that, already just the two of them were always going about together.

With that the two of them carried snow.

When the two of them lived together, in the lake of the woman mountain a young mountain came out, and that was Black mountain.

He was, they say, the son of Imbabura mountain.

With that Taita Imbabura, getting older, could no longer walk about, so much his head, his head, began to hurt, at times his head remains shrouded.

Striking in this story is the tone of ordinary familiarity - Lord or Father Imbabura is portrayed as an average young fellow, who carries on with a woman in his vicinity, produces with her a son, and then begins to feel the pains of old age. This would seem to be a story told about a friendly uncle rather than about a powerful spiritual presence.

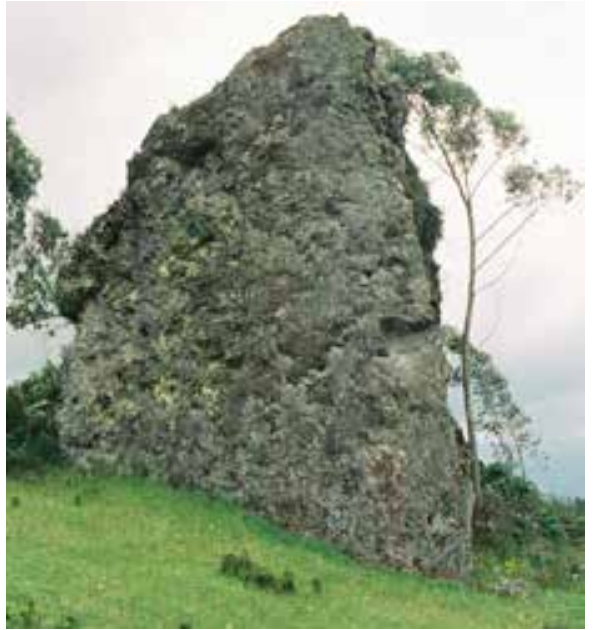

Wando Rumi, the rock sent across the valley by Mama Cotacachi

\section{Story 2: "Wando Rumi"}

Continuing the theme of mountains as lovers, there is a story I heard repeatedly from my Otavalo Runa friends about the souring of the relationship between Taita Imbabura and Mama Cotacachi. I convey here the gist of this tale, compiled from many tellings:

Taita Imbabura and Mama Cotacachi were lovers, and they came together to produce Black Mountain, their off-spring. But later they began to quarrel. Maybe the Taita was seeing another woman, or maybe he wasn't paying enough attention to Mama Cotacachi. In any case, she'd had enough of him, and one day, in a fit of anger, she flung a large rock across the 
valley, hoping to bean him on the head. But she was not strong enough to land the rock on his head - it only made it to his shoulder. And today, way up the flank of the mountain, you can see that rock, the one Mama Cotacachi threw at the Taita when she was angry with him. And indeed, if you walk up the slope of Imbabura a couple of hours above the town of Ilumán, you will come across a massive rock, in reality, a pair of enormous boulders, alone on the flank of the mountain. But once again, I am struck with the tone of this narrative, depicting a lover's quarrel and an act of jealous rage, between these powerful spiritual forces in the Otavalo Runa cosmology.

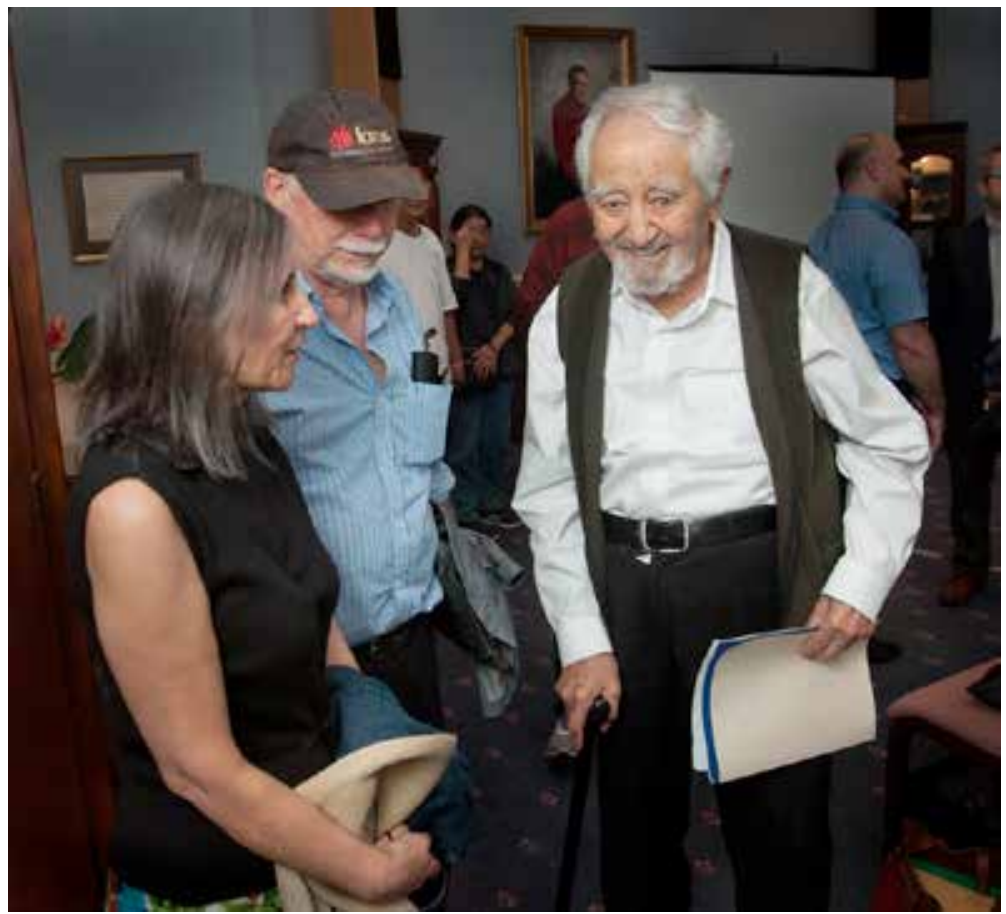

Jon and Pat McDowell with Ilhan Basgoz

\section{Story 3: "Taita Imbabura as Puñu Shiki (Lazy Ass)"}

The comical and familiar tendencies in this repertoire come out most clearly in the story of Taita Imbabura as a "lazy ass." Again, I summarize the tale from the many tellings I witnessed:

At the dawn of time, when the land was just taking shape, all the mountains were invited to go out looking for water to place on their slopes and in the valleys. Mama Cotacachi was one of the first ones to go out looking for water, and she found a fine lake, Cuicocha, to take back home with her. For this reason, there is always water to be found on Mama Cotacachi. But Taita Imbabura was lazy - he did not feel like going out looking for water. Finally, when he got around to looking for water, there was none left. Consequently, Taita Imbabura is dry - he has nothing in the way of lakes and rivers like the other mountains. He turned out to be a puñu shiki, a lazy ass. 
Here we move further away from reverence, through familiarity to approach contempt. Taita Imbabura is portrayed as a slacker who missed out on the opportunity to provide himself with water at an early juncture in cosmic history when water was available to those who would seek it. The term "lazy ass" is used in Quichua to poke fun at people who do not show the proper initiative in life. I have heard it mostly in a mood of friendly criticism, and that seems to be the tenor of this popular narrative.

\section{Conclusion}

The evidence from Ecuador's Otavalo Runa presents a difficulty to any simplistic notions about the quality of spiritual experience. This combination of reverence and mirth in beliefs, tales, and practices associated with Taita Imbabura, appears to be, on the face of things, a contradiction in terms - how can one simultaneously revere the power of a deity and mock this very same deity? I believe that the answer to this puzzle lies in the peculiar qualities of the personal relationship the Otavalo Runa establish with this deity, this mountain lord on whose very slopes they live and whose soil nourishes their families. The possibility of a personal relationship entails the attribution of character traits to the deity, traits that enable a sentiment of intimacy of the sort familiar in relationships between human beings.

In closing, I'd like to present this data and my discussion of it as a contribution to understanding the complexities of the religious experience. In an earlier contribution (McDowell 2002), I drew on the work of Philip Wheelwright, an American literary scholar of the mid-twentieth century, to access some dimensions of belief in the sacred as manifested in the phrases and sentences of mythic narrative. Specifically, Wheelwright offers the argument that "the genuinely religious believer is one who gives full commitment, not to the sentences in their literal meanings...but to some half-guessed, half-hidden truth which the sentences symbolize" (1965: 166). This analysis lays bare an essential continuum running from literal and abstract belief in religious phenomenon.

The Otavalo Runa attitudes toward Taita Imbabura, the mountain deity associated with the mountain that embraces and nurtures them, opens up a perspective on another continuum that will prove vital, I believe, in defining the range of religious experiences. This continuum runs between the well-known pole of reverence, with its connotations of awe, solemnity, and worship, and the less-recognized pole of mirth, born of familiarity, even intimacy, in the relationship between the deity and the person. As the options along these sets of variables make clear, there is no one, single way to approach the sacred, and mythic narrative, the stories people tell about the figures they hold to be sacred, may range in tone from the reverential to the mirthful, from worshipful to hilarious, from the solemn to the comical.

We have dealt here with a case study from the Andean region of Ecuador, but clearly this ambivalence in religious discourse is widespread in the world's cultures. The American folklorist Barre Toelken (19xx) helped us appreciate coyote, the Navajo trickster figure, as both a powerful mythical presence and an often amusing character. Likewise, we could include in this category the Turkish trickster figure Nasreddin Hoja, who, as Ilhan Basgoz (1998) instructs in his valuable accounts of Turkish folklore, possesses both saintly and comical attributes. 


\section{Works cited}

Basgöz, I. (1998). Turkish folklore and oral literature: Selected essays of Ilhan Basgoz. Edited by K. Silay. Bloomington: Indiana University Turkish Studies.

Hymes, D. (1981). In vain I tried to tell you: Essays in Native American Ethnopoetics. Philadelphia: University of Pennsylvania.

McDowell, J. (2002). From expressive language to mythemes: Meaning in mythic narratives. In Myth, A New Symposium. (G. Schrempp and W. Hansen, ed.) Bloomington: Indiana University.

Moya, R. (1987). Taruca: Ecuador Quichuacunapac Rimashca Rimaicuna - La Venada: Literatura oral Quichua del Ecuador. Fausto Jara, storyteller, Ruth Moya, translator. Quito: CEDIME.

Toelken, B. (1969). The 'Pretty languages' of Yellowman: Genre, mode, and texture in navaho coyote narratives. Genre 2, pp. 211-235.

Wheelwright, P. (1965). The semantic approach to myth. In Myth, A Symposium, edited by A. Sebeok, T. 154-68. Bloomington: Indiana University.

Wibbelsman, M. (2005). Otavalos at the crossroads: Physical and metaphysical coordinates of an indigenous world. Journal of Latin American Anthropology. No.10, pp. 151-185. 